\title{
ISLAM DAN TOLERANSI BERAGAMA DALAM MASYARAKAT MUSLIM KANAYATN DAYAK DI KALIMANTAN BARAT
}

\author{
Hermansyah \\ STAIN Pontianak, Jl. Letjen Suprapto No. 19 Pontianak, \\ hermansyahii@yahoo.com
}

\begin{abstract}
The object of this study is Islam in Dayak communities; a subject that is rarely being studied. It tries to expose some interesting facts about Islam in these isolated communities. Many have hitherto thought that the Dayak communities are primitive with no particular affiliation to any formal religion. This paper tries to show the reverse. The truth is that these communities do even have reasonably developed view of Islam especially that which has to do the problem of tolerance and social life. The basic premise that this paper adopts is that a practice is form of paradigm; the way a particular society performs social life reflects their orientation of religious understanding. Hence, although the Dayak communities do not have paradigmatic understanding of Islam-in the strictest sense of the word-they do nonetheless have a practical discourse that emerge out of their unique and perhaps simple understanding of their religion. Relevant to the study of this object is the issue of community identity and how this issue is related to the religious identity. Hence, the paper is interested in exposing the tension between the two identities in the context of the Dayak communities in West Kalimantan.
\end{abstract}

Keywords: Tolerance, practical discourse, community identity, religious identity.

\section{Pendahuluan}

Tulisan ini akan mengulas mengenai keberislaman yang dianut sekelompok masyarakat di beberapa kampung yang terletak di Kabupaten Landak, Kalimantan Barat. Kajian mengenai masyarakat yang belum terlalu lama masuk Islam (mu'allaf) di Pedalaman Dekat di Kalimantan Barat dapat dikatakan belum ada. Bagaimana proses masuk Islam, bagaimana pengamalan Islam, bagaimana hubungan 
mereka dengan pemeluk agama asal, adalah merupakan sederetan pertanyaan yang belum ada jawaban tentang mu'allaf di Kalimantan Barat. Padahal jumlah mereka boleh dikatakan relatif banyak. Terlebih proses masuknya Islam di beberapa daerah masih terus berlangsung hingga saat ini. Menurut Kepala Kantor Wilayah Departemen Agama Kalimantan Barat, dilaporkan setiap tahun terjadi penambahan tidak kurang dari seribu orang mu'allaf baru. ${ }^{1}$ Namun tidak sedikit pula yang kembali ke agama asal karena kurangnya pembinaan.

Karena ketiadaan kajian, banyak masyarakat yang tidak mengerti bahwa pada tempat-tempat tertentu, terutama di kampung-kampung Dayak seperti di Hulu Sintang, di pelosok Kabupaten Landak dan Bengkayang, terdapat penganut Islam yang berasal dari penduduk asli. Bahkan di kampung-kampung tertentu di daerah ini Islam sudah menjadi agama mayoritas di kalangan penduduk. Keberadaan mereka ini memang tidak terlalu menonjol. Hal ini antara lain disebabkan karena kurangnya publikasi di samping karena peralihan agama di tempat ini tidak serta-merta menyebabkan peralihan identitas. Berbeda keadaannya dengan yang terjadi lebih dari 150 tahun yang lalu di Kapuas Hulu misalnya, penduduk asli yang menganut agama Islam otomatis menjadi Melayu. ${ }^{2}$ Di sini, mereka tetap bangga mengaku memiliki identitas etnik sebagai orang Dayak atau identitas lokal yang lazim digunakan. Di Kalimantan Barat, istilah Dayak biasanya digunakan oleh para peneliti luar negeri merujuk kepada penduduk asli Kalimantan Barat, terutama yang non-Muslim. Penggunaan istilah Dayak yang merujuk pada penduduk lokal yang bukan penganut Islam diyakini dipelopori para petugas kolonial Belanda sejak lebih dari 150 tahun yang lalu. Pada kenyataaannya, banyak kelompok masyarakat yang dikategorikan Dayak tidak menyebut dirinya sebagai Dayak. Sebagian mereka lebih senang disebut dengan nama etnik asli yang digunakan sehari-hari. Sebagai contoh, orang Mmayan di Selimbau, Kapuas Hulu, tetap menyebut diri orang Mmayan padahal ada tiga agama yang dipeluk penduduk

${ }^{1}$ Rasmi Sattar, Wawancara, Pontianak, 3 Oktober 2009.

2 Moh. Haitam, Hermansyah \& Yusriadi, "Islam di Pedalaman Kalimantan Barat: Studi Kasus atas Keberagamaan Masyarakat Embau”, Laporan Penelitian pada Sekolah Tinggi Agama Islam Negeri (STAIN) Pontianak, 2010; Hermansyah, Imu Gaib di Kalimantan Barat (Jakarta: Gramedia, EFEO, KITLV, dan STAIN, 2010), 20. 
setempat; Katolik, Protestan dan Islam. ${ }^{3}$ Lebih dari seratus nama etnik yang tetap digunakan sampai hari ini. Nama-nama etnik itu antara lain: Iban, Punan, Kayan, Bukat, Mualang, Bekati', Bidayuh, Kantu', Taman, Desa, Tebidah dan sebagainya. Bahkan, di Sintang muncul organisasi Ikatan Keluarga Besar Dayak Muslim.

Salah satu bagian komunitas asli Kalimantan Barat yang terus melakukan konversi agama asal kepada Islam adalah orang Kanayatn. Satu komunitas masyarakat asli Kalimantan Barat yang jumlahnya relatif banyak yang terdapat di Kabuapten Landak. Jumlah orang Kanayatn tidak pasti. Menurut Badan Pusat Statistik (2000) menyebutkan orang Kanayatn sebanyak 292.390 atau 8\% dari total populasi penduduk Kalimantan Barat. Sedangkan menurut Thomas et.al $(1984 ; 1985)^{4}$ memperkirakan sekitar 350.000 orang Kanayatn. Orang Kanayatn tidak hanya di Kabupaten Landak, tetapi juga tersebar di Kabupaten Pontianak dan Kabupaten Bengkayang.

Secara khusus tulisan ini akan menggambarkan kehidupan sosioreligius masyarakat Kanayatn yang baru memeluk Islam serta hubungan mereka dengan penduduk setempat yang bukan Islam.

Penelitian ini menggunakan metode etnografi. Dalam penelitian lapangan ini, peneliti memainkan dua peranan, yaitu peneliti sebagai penjaring data sosial tetapi sekaligus juga sebagai "participant observer", yang berinteraksi dengan masyarakat. Dengan peran ini peneliti berupaya memahami aspek yang diteliti sebagaimana masyarakat memahaminya di samping menggunakan sudut pandang sendiri dalam memaknainya. ${ }^{5}$ Berkenaan dengan hal ini Bernard mengatakan ethnography is about understanding people's live experiences. This kind of information requires a few knowledgable and articulate informants rather than unbiased sample of people. Ethnography is also about emic explanation of how things work. ${ }^{6}$

Sebagaimana umumnya dalam penelitian kualitatif, teknik penentuan sumber data dalam penelitian ini menggunakan pendekatan

3 James T. Collins, Linguistik Sejarawi: Prinsip dan Amalan Perbandingan Bahasa (Pusat Bahasa dan Linguistik, Fakulti Sain Sosial dan Kemanusiaan, Universiti Kebangsaan Malaysia, 2005), 4-6.

${ }^{4}$ Alexander K. Adelaar, Salako or Badameà: Sketch Grammar, Texts, and Lexicon of a Kanayatn Dialect in West Borneo (Wiesbaden: Otto Harrassowitz, 2005).

5 James P. Spradley, Metode Etnografi, terj. Misbah Elizabeth (Yogyakarta: Tiara Wacana, 1997), 30.

${ }^{6}$ Russell Bernard H., Social Research Methods: Qualitative and Quantitative Approaches (California: Sage Publications, 2000), 345. 
sampel bertujuan (purposive sampling). ${ }^{7}$ Adapun yang menjadi informan dalam penelitian ini adalah mereka yang dianggap mengetahui masalah yang diteliti. Mereka adalah orang-orang yang dihormati di kampung, misalnya tokoh Islam, tokoh adat, dan pengurus desa. Sebagai pembanding ada pula penduduk kampung biasa yang dijadikan informan. Pengambilan data dihentikan manakala data yang ingin diperoleh sudah mencapai titik jenuh atau berulang-ulang. ${ }^{8}$

\section{Deskripsi tentang Masyarakat Kanayatn}

Penting dicatat di sini bahwa kerajaan Landak yang letaknya agak jauh dari pesisir pada abad ke-16 sudah menjadi kerajaan Islam. Proses islamisasi ini berlangsung melalui hubungan dengan kerajaan Banten. Sejarah mencatat Kerajaan Landak ini memiliki hubungan yang harmonis dengan kerajaan Banten di Jawa. Bahkan pada tahun 1698, Raja Landak yang pada masa itu sedang berperang dengan Sukadana telah memohon bantuan kepada Sultan Banten. ${ }^{9}$ Karena berbagai hambatan usaha islamisasi yang dilakukan melalui kesultanan pesisir ini agak terbatas, sehingga daerah "Pedalaman Dekat" agak terlambat dalam menerima agama Islam. Sebagian kampung di kawasan "Pedalaman Dekat" ini baru menerima Islam pada era 1980an dan proses konversi dari agama sebelumnya masih berlangsung sampai hari ini. Tentu saja, keberagamaan masyarakat yang relatif baru ini berbeda dengan corak beragama masyarakat di tempat yang lebih dahulu memeluk Islam.

Desa Gunung merupakan salah satu desa yang terletak di Kabupaten Landak. Batas terdekat desa ini terletak kurang lebih $6 \mathrm{~km}$ dari desa Sebilang, yang terletak di jalan utama, atau kurang lebih 150 $\mathrm{km}$ dari kota Pontianak, ibukota provinsi Kalimantan Barat. Untuk mencapai desa ini dari jalan utama dapat ditempuh dengan menggunakan jalan darat. Sarana angkutan yang menghubungkan desa ini adalah dengan ojek sepeda motor atau angkutan umum sejenis pick up. Namun, jumlah angkutan umum ini sangat terbatas, hanya satu buah. Itupun hanya tiga kali sehari mengangkut penumpang: pagi, tengah, dan sore hari. Umumnya, yang menggunakan jasa angkutan

\footnotetext{
${ }^{7}$ K.F. Punch, Introduction to Social Research (London, New Delhi: Sage Publication, 2001), 193.

${ }^{8}$ Lexy J. Moleong, Metodologi Penelitian Kualitatif (Bandung: Remaja Rosda Karya, 1996), 165.

${ }^{9}$ Graham Irwin, Borneo Abad ke-19, terj. Moh. Nor Ghani \& Noraini Ismail (Kuala Lumpur: Dewan Bahasa dan Pustaka, 1986), 4 dan 6.
} 
umum ini adalah para pelajar, sebab tarifnya relatif murah dan sesuai dengan jadwal masuk dan pulang Sekolah Menengah Pertama (SMP) dan Sekolah Menengah Atas (SMA) Karya Yosef Sebilang. ${ }^{10}$

Menurut catatan Kepala Desa Gunung, penduduk desa yang terdiri dari lima dusun ini berjumlah 3623 jiwa dari 640 Kepala Keluarga (KK). Masyarakat Gunung sangat bangga mengaku sebagai orang Dayak, apapun agamanya. Dayak memang menjadi identitas bersama masyarakat Gunung jika bertemu dengan orang luar daerahnya. Seorang informan Muslim yang bernama Apit dengan bangga menyebut dirinya sebagai "Andas", sebuah akronim Anak Dayak Asli. Selain Dayak, masyarakat Gunung memiliki identitas lain yang umumnya erat terkait dengan letak geografi tempat tinggalnya sebagaimana lazimnya masyarakat yang ada di Kalimantan Barat. Sebagai contoh, Apin, seorang penduduk kampung Kunir sesekali menyebut dirinya orang Sangah atau orang Ahe atau orang Kanayatn. ${ }^{11}$

Masyarakat Gunung umumnya pandai berbicara dan terbuka terhadap semua orang, termasuk yang baru dikenal. Mereka juga umumnya memiliki suara yang merdu. Ini mungkin berkaitan dengan kebiasaan mereka melantunkan mantra untuk sesuatu yang dihormati seperti padi. Wajar jika sangat banyak lagu yang dihasilkan oleh orang Kanayatn umumnya.

Tingkat pendidikan penduduk relatif rendah. Sebagian besar penduduk hanya berpendidikan Sekolah Dasar. Bahkan, banyak juga penduduk yang sama sekali tidak mengenyam pendidikan. Di desa itu hanya terdapat dua buah SD dan sebuah Sekolah Menengah Pertama (SMP). Untuk melanjutkan pendidikan ke Sekolah Menengah Atas (SMA) terdekat, mereka harus bersekolah ke ibukota kecamatan.

Masyarakat Gunung umumnya bekerja di sektor pertanian yang digarap secara tradisional. Mereka sangat bergantung kepada kemurahan alam. Keadaan alam yang tidak menentu, serangan hama, dan berbagai gangguan lainnya menghadirkan kekhawatiran di benak mereka. Perasaan khawatir dan takut terhadap hal-hal yang berada di luar jangkauan akan pikiran itu menyebabkan mereka hidup di bawah tekanan, karena selalu merasa terancam. Bahkan kuasa jahat begitu dekat dengan mereka. Di antara kuasa jahat itu adalah Kamakng. Kamakng tinggal di Bukit Manuk arah utara kampung Kunir. Kamakng

10 Observasi, Desa Gunung 3 Oktober 2009.

${ }^{11}$ Ibid. 
dapat dipanggil untuk membantu manusia. Pada masa peperangan, Kamakng Tariu—salah satu nama Kamakng — yang ada di Bukit Manuk diundang melalui sebuah upacara, yang dilakukan pohon beringin yang terletak di hutan Etat arah Barat kampung Kunir, untuk membantu. ${ }^{12}$

Semua itu menyebabkan mereka meyakini sesuatu yang adikodrati sebagai Tuhan. Untuk menciptakan harmoni, mereka melakukan berbagai upacara adat dan menetapkan pantang larang yang sangat banyak.

Sebagaimana umumnya masyarakat pedalaman Kalimantan, menanam padi huma (ladang) adalah bidang pertanian utama masyarakat Gunung. ${ }^{13}$ Boleh dikatakan menanam padi merupakan inti pertanian masyarakat Gunung. Ada dua sistem bertanam padibahuma - pada masyarakat Gunung yakni berladang (padi munggu') dan bersawah. Mereka bertani dengan cara tradisional. Berhasil dan gagalnya pertanian sangat bergantung pada kemurahan alam, sebagaimana seluruh sistem kehidupan yang lain. Dengan demikian, tidak mengherankan pada masyarakat Gunung sangat banyak upacara adat yang berkenaan dengan padi. Bagi mereka padi harus diperlakukan dengan penuh hormat, sebab padi memiliki sumangat, sama halnya manusia. Penghormatan terhadap padi bisa dilihat pada proses mereka mengolah padi dengan penuh kehati-hatian semenjak masa persiapan sampai pasca-panen. Secara khusus, penghormatan diwujudkan pada ragam upacara pada seluruh siklus penanaman padi. Pesta panen padi-Naik Dango-merupakan upacara utama dalam masyarakat Gunung yang melambangkan pentingnya padi bagi mereka sekaligus memiliki nilai religius dan sosial. Penghormatan pada padi juga nampak dalam salah satu mantra berikut ini:

Mantra untuk menanam padi

Bismilah saya akan mengunci padi ini

Iiiiii' done' kata done'

Kata doyoh hop pakadom jorom sibayom

Siti patimah roh ranjani. ${ }^{14}$

\footnotetext{
12 Ibid.

13 Michael R. Dove, Swidden Agriculture in Indonesia: The Subsistence Strategies of the Kalimantan Kantu (Berlin, New York \& Amsterdam: Mouton Publishers, 1985).

14 Apit, Wawancara, Desa Gunung, 15 Januari 2007. Terjemahan bebasnya: Bismillah saya akan mengunci [menjaga] padi ini, Iiiiii' done' kata done', Kata doyob hop pakadom jorom sibayom, Siti Fatimah roh ranjani.
} 
Dalam upacara yang berkaitan dengan padi huma, masyarakat Gunung selalu menggunakan binatang terutama ayam dan babi. Menurut seorang informan, dalam seluruh siklus padi huma, jika dilakukan semuanya, tidak kurang 40 ekor ayam yang digunakan untuk keperluan upacara. Sampai pada tahun 2005, panen padi hanya boleh dilakukan dengan menggunakan ani-ani. Sejalan dengan semakin meningkatnya pengetahuan masyarakat, maka sejak tahun 2006 sebagian masyarakat sudah memanen padi dengan menggunakan sabit walaupun sebagiannya masih mempertahankan cara lama. ${ }^{15}$

Sikap orang Gunung terhadap padi huma merupakan sikap yang lazim terdapat pada masyarakat di Nusantara. Collins ${ }^{16}$ menggambarkan sikap orang Tioman (Malaysia) pada seluruh siklus huma padi sejak penanaman sampai masa panen-yang terbagi mejadi tiga tahap besar-sebagai sesuatu yang sangat rumit sekaligus indah. Skeat ${ }^{17}$ menguraikan secara terperinci kepercayaan dan ritual yang berkenaan dengan padi. Uraian Skeat tersebut seluruhnya menggambarkan bahwa padi adalah sumber kehidupan yang mesti diperlakukan dengan hati-hati.

Skeat menggambarkan pentingnya beragam ritual penghormatan dalam menanam padi itu karena anggapan bahwa tumbuh-tumbuhan itu juga dihuni oleh roh, sehingga tidak heran jika ada ritual-ritual tersebut sebagai wujud penghormatan. ${ }^{18}$ Hermansyah dalam penelitiannya menyatakan bahwa cara memperlakukan padi dengan sangat hormat merupakan hal yang lazim dilakukan oleh masyarakat Embau, sebuah kawasan orang Melayu di kabupaten Kapuas Hulu. Ritual yang dilakukan setahun sekali itu merupakan simbol "perjalanan" mencari rezeki. Panen padi adalah memetik hasil "perjalanan". Menanam padi bagi orang Embau digambarkan sebagai mengirim padi untuk melakukan perjalanan mencari laba, untung tuah dan sutera yang indah. Padi ditimang dan diberi nama julukan wal rabi wal rafi rafi mustafa rasululah seperti tergambar dalam mantra menanm padi orang Embau. Padi diberi bekal seperti kunyit, sabang (sejenis pohon palm kecil), juaran (lenjuang; Cordyline fruticosa) dan ubi jalar

\footnotetext{
15 Observasi, Desa Gunung, 15 November 2009.

${ }^{16}$ James T. Collins, "Bahasa Pantang Larang di Pulau Tioman: Releksifikasi Semasa Menuai", Jurnal Dewan Bahasa, 36: 916-933 (1992), 924.

17 W.W. Skeat, Malay Magic: Being an Introduction to the Folklore and Popular Religion of the Malay Peninsula (New York: Dover Publication, 1967), 218-249.

${ }^{18}$ Ibid.
} 
(Ipomoea batatas) dan batu asah. Bekal ini diletakkan di mpalang bonih (tempat pertama kali menanam benih).

Selain sebagai petani padi, masyarakat Gunung terkadang bekerja sebagai penyadap karet. Bekerja menyadap karet merupakan cara untuk menghasilkan uang, yang digunakan untuk memenuhi kebutuhan sehari-hari di luar beras. Di samping itu mereka juga menanam sedikit coklat, tengkawang, dan berbagai jenis tanaman yang menghasilkan buah-buahan. Kebanyakan tanaman itu merupakan warisan leluhur di mana belum diusahakan penganganannya secara modern dan profesional. Akhir-akhir ini juga dikembangkan perkebunan sawit. Perkebunan sawit yang luas umumnya dimiliki oleh perusahaan besar. ${ }^{19}$

Pekerjaan lain yang dilakukan oleh masyarakat Gunung untuk menambah penghasilan adalah dengan berternak. Hewan yang biasa diternak oleh masyarakat Gunung adalah babi, ayam, itik, kambing, dan sapi. Jumlah hewan ternak yang dipelihara masyarakat Gunung umumnya dalam jumlah yang sedikit. Oleh karena itu, pekerjaan berternak merupakan pekerjaan sampingan masyarakat Gunung. Dalam memelihara hewan ternak, biasanya orang Gunung melakukannya dengan cara tradisional, yaitu dengan melepaskan hewan tersebut untuk mencari makan sendiri. Beberapa orang di antara penduduk desa Gunung juga ada yang memelihara ikan. Selain itu, kadang-kadang mereka juga berburu binatang. ${ }^{20}$

Sebagian hasil pertanian, perkebunan, peternakan dan perikanan masyarakat dibawa ke luar untuk dijual. Sebaliknya dari luar dibawa berbagai keperluan yang tidak dapat dipenuhi sendiri oleh masyarakat. Transaksi ekonomi ini membuka peluang bagi orang Gunung untuk berhubungan dengan orang luar. Hal ini didukung oleh akses jalan memungkinkan masyarakat Gunung maupun masyarakat luar untuk keluar masuk ke desa ini. Keadaan ini pula yang memungkinkan para misionaris Kristen dan Katolik serta pendakwah Islam dapat mencapai desa ini.

Tidak ada data resmi tentang pemeluk agama di Gunung. Selain sebagai penganut agama tradisional, sebagian penduduk memeluk agama Katolik, Protestan dan Islam.

19 Observasi, Desa Gunung, 5 Desember 2009.

${ }^{20}$ Ibid. 


\section{Corak Religiusitas Masyarakat Kanayatn}

Beberapa Orang Kanayatn di desa Gunung relatif belum terlalu lama memeluk agama Islam, karena Islam masuk di daerah tersebut kira-kira seperempat abad silam. Ada berbagai alasan mengapa masyarakat Gunung memeluk Islam, di antaranya karena mereka merasa tidak mendapatkan ketenteraman dalam agama lama, terutama berkaitan dengan aspek teologi. Ada juga yang memilih Islam karena dibesarkan oleh keluarga Islam, terutama orang-orang Madura yang mengangkat mereka sebagai anak angkat sebelum kerusuhan sosial tahun 1997. Selain itu, ada juga yang memeluk Islam karena mengikuti agama anggota keluarga lain. Namun, ada juga yang masuk agama Islam karena alasan yang lebih pragmatis, yakni menikah dengan orang Islam. ${ }^{21}$

Secara umum perkembangan Islam baik dalam arti kuantitas maupun kualitas belum menunjukkan kemajuan signifikan. Hal ini antara lain disebabkan oleh sangat kuatnya adat-istiadat mereka, sehingga kesan yang timbul adalah bahwa agama nyaris tidak mampu merubah kehidupan masyarakat setelah mereka memeluk Islam. Bahkan, beberapa informan menyatakan bahwa salah satu hambatan masyarakat Gunung memilih Islam, karena agama ini menganggap babi najis. Sementara babi bagi masyarakat Gunung merupakan salah satu peralatan adat yang utama. Di lain pihak, sangat jarang ada pembinaan keagamaan kepada mereka. Kalaupun ada hanya sekalisekali, itupun hanya di kampung-kampung tertentu saja. Walaupun begitu, keinginan masyarakat Gunung untuk memeluk Islam cukup tinggi. Sampai sekarang setiap tahunnya ada penduduk Gunung yang datang ke Pontianak atau kampung sekitar untuk menyatakan keislamannya.

Tidak diperoleh data yang pasti tentang jumlah penduduk Gunung yang menganut Islam. Sampai saat ini tidak ada catatan resmi mengenai penduduk yang beragama Islam. Kesukaran untuk mendapatkan data jumlah penduduk Muslim di Gunung disebabkan karena identitas agama belum menjadi identitas yang penting bagi mereka. Ditambah lagi sebagai kelompok minoritas, pengakuan sebagai orang Islam tidaklah menguntungkan, kecuali pada situasi tertentu. Berdasarkan informasi beberapa informan diperkirakan tidak kurang dari $20 \mathrm{KK}$ penduduk Gunung sudah memeluk Islam.

21 Ibid. 
Sebenarnya hubungan masyarakat di sana dengan Islam relatif cukup lama bahkan sebelum agama ini didakwahkan dan kemudian diterima sebagai agama oleh sebagian masyarakat. Hubungan ini nampak terutama dalam budaya pinjaman yang dapat ditelusuri berasal dari tradisi penganut agama Islam. Beberapa mantra yang diamalkan oleh masyarakat membuktikan hal ini. Berikut contohcontohnya:

Mantra api/air panas untuk mendinginkan

Bi ism Allâh yâ Raḥmân yâ Rahịm

Turun jaki naik jai

Makan rokok sirih sakabat

Bukan aku nawari' kena' apil air

Aku nawari' bujan yang lebat. ${ }^{22}$

Mantra mata untuk penyakit mata

Bi ism Allâh yâ Raḥmân yâ Rahịm

Ambun ijau ambun kuning

Ambun manikam raja manawar

Aku nuruntan tawaran saribu

Anak ikan putib dari lautan

Panas sajuk barat ringan

Tajam tumpul bisa tawar

Sah tawar. ${ }^{23}$

Mantra Kempunan untuk sakit karena kekuatan gaib

Bi ism Allâh yâ Raḥmân yâ Raḥim

Pariu' si parunggu

Barisi' ruman padi

Turun dato' petara guru

Nawari' kempunan ku tadi'

Jilat makatn. $^{24}$

22 Apan, Wawancara, Desa Gunung, 17 Januari 2007. Terjemahan bebasnya: Bi ism Allâh yâ rạ̣mân yâ Rabîm, Turun jaki naik Jai, Makan rokok sirih seikat, bukan aku menawarkan [orang yang] terkena api/air [panas], aku menawarkan hujan yang lebat.

23 Maria Ate, Wawancara, Desa Gunung, 16 Januari 2007. Terjemahan bebasnya: Bi ism Allâh yâ raḅmân yâ Rahî̀m, embun hijau embun kuning, embun menikam raja menawar, aku menurunkan tawar seribu, anak ikan putih dari lautan, panas sejuk berat ringan, tajam tumpul tawar bisa, sah tawar.

24 Alau Akbar, Wawancara, Desa Gunung, 15 Januari 2007. Terjemahan bebasnya: Bi ism Allâh yâ rạ̣mân yâ Rahîm, pariu' si parunggu, berisi tangkai padi, turun datok petara guru, menawarkan kempunan aku tadi, jilat makan. 
Kata-kata bi ism Allâh al-Raḥmân al-Raḩîm atau kadang-kadang diucap bi ism Allâh yâ Raḥmân yâ Rahîm yang terdapat dalam mantramantra di atas dapat dipastikan berasal dari sistem kepercayaan Islam. Mantra-mantra ini diperoleh dan diamalkan oleh mereka sejak sebelum memeluk Islam. Inilah satu di antara sebab, Islam dapat diterima oleh orang Gunung. Kepercayaan terhadap kekuatan supranatural yang sudah tertanam secara kuat mendapat tempat dalam ajaran Islam. Beberapa aspek kepercayaan itu mirip dengan kepercayaan Islam seperti konsep tentang Tuhan yang disebut Jubata. Bahkan, ada informan yang mengaku semakin yakin dengan Islam ketika mengetahui bahwa sebagian atau keseluruhan bacaan mantramantra yang diamalkannya berasal dari ajaran Islam. Keadaan ini bisa dibandingkan peralihan agama seorang raja Patani, kawasan Thailand Selatan, menjadi Islam setelah disembuhkan oleh seorang shaykh dari Pasai. Setelah jumlah penduduk Muslim di daerah tersebut semakin signifikan, praktik semacam ini tidak serta-merta hilang. Di Menggala, daerah Lampung Utara, masyarakat masih menggunakan magi untuk keperluan pengobatan. Magi tersebut merupakan gabungan antara kepercayaan lokal dengan Islam. ${ }^{25}$ Pemanfaatan sumber-sumber lokal untuk islamisasi dilakukan oleh elit lokal Islam dalam rangka penyebaran agama ini yang disesuaikan dengan masyarakat desa yang sinkretik. Mulkhan menyebut proses islamisasi yang demikian dengan "domestikasi" atau penjinakan Islam. ${ }^{26}$

Dalam konteks yang lebih luas hampir tidak ada perbedaan antara orang Islam dan bukan Islam di Desa Gunung. Kebiasaan kehidupan sehari-hari masyarakat Gunung seperti memelihara anjing juga masih diamalkan oleh mereka yang memeluk Islam. Bahkan di beberapa rumah orang Islam Gunung, anjing dengan bebas berkeliaran di rumah. Keadaan ini berbeda dengan orang Islam di Landau Kumpang, Kapuas Hulu yang juga memelihara anjing. Orang Islam di Landau Kumpang memelihara anjing untuk menjaga kebun dan ladang, sama sekali mereka tidak membiarkan anjing masuk ke dalam rumah. $^{27}$

25 Julia Maria, Kebudayaan Orang Menggala (Jakarta: UI Press, 1993), 90-97. Hal yang serupa juga terjadi di kalangan orang Banjar di Kalimantan Selatan. Lihat Alfani Daud, Islam dan Masyarakat Banjar: Diskripsi Analisa Kebudayaan Banjar (Jakarta: RajaGrafindo Persada, 1997), 366-436.

26 Abdul Munir Mulkhan, Neo-sufisme dan Pudarnya Fundamentalisme di Pedesaan (Yogyakarta: UII Press, 2000), 36, 40.

${ }^{27}$ Hermansyah, Ilmu Gaib, 27. 
Sebagaimana sudah dikemukakan di atas bahwa orang Gunung memiliki banyak kepercayaan yang melahirkan pantang larang dan upacara adat. Seperti juga kebiasaan kehidupan sehari-hari, aspek spiritualitas agama tradisional-yang mereka sebut adat-masih melekat erat dalam kehidupan masyarakat Islam di Desa Gunung. Hampir seluruh ekspresi kepercayaan lokal masih dijalankan oleh orang Islam di Desa Gunung. Mereka umumnya secara tegas memisahkan antara agama dan adat. Karenanya tidak ada hambatan bagi mereka untuk menjalankan ritual adat karena dianggap sebagai sesuatu yang terpisah dari agama. Ringkasnya, bentuk kepercayaan lama tidak sepenuhnya hilang, atau malah sebagian besarnya masih dipraktikkan oleh masyarakat setempat. Berkenaan dengan fenomena ini, Lapidus menyatakan:

While many Muslims adhered to the high tradition defined by ulama and Sufi teachings, many, if not most lived in a mental world defined by the heritage of local cultures. For most Southeast Asia villagers, Islam was an element of a more complex social and religious identity and not the exclusive symbol of personal and collective life. ${ }^{28}$

Kenyataan itu tidak lepas dari kesadaran pendakwah Islam di kawasan ini. Watak Islam yang toleran sehingga melahirkan corak Islam yang khas sesungguhnya menjadi ciri umum keberislaman di Nusantara. Bahkan beberapa peneliti berkesimpulan bahwa pertemuan antara kepercayaan tradisional dengan Islam inilah yang menjadi salah satu rahasia keberhasilan Islam di Nusantara. ${ }^{29}$

Corak Islam semacam ini hampir merata di seluruh Nusantara, terutama pada tahap awal islamiasi. Oleh sebagian peneliti, di antaranya Landon, Islam di kawasan ini dianggap sebagai Islam periferal. Islam hanya dianggap sebagai lapisan tipis di atas kebudayaan lokal. ${ }^{30}$ Dengan nada yang serupa Van Leur menyebutkan bahwa, "Terhadap Indonesia, Islam tidak membawa pembaruan sepotong pun ke tingkat perkembangan lebih tinggi, baik secara sosial,

\footnotetext{
28 Ira M. Lapidus, A History of Islamic Societies (Cambridge: Cambridge University Press, 1991), 487-488.

${ }^{29}$ Ibid., 468. Lihat juga Robert N. Bellah, Beyond Belief: Menemukan Kembali Agama, Esei-esei tentang Agama di Dunia Modern, terj. Rudy Harisyah Alam (Jakarta: Paramadina, 2000).

${ }^{30}$ K.P. Landon, Southeast Asia: Crossroad of Religion (Chicago: University of Chicago Press, 1949), 136-164.
} 
ekonomi maupun pada dataran negara atau perdagangan."31 Pernyataan ini boleh jadi benar terutama pada masa-masa Islam pertama kali diterima oleh penduduk lokal. Namun, ketika Islam sudah diterima secara massal serta melalui proses pendidikan yang panjang, Islam sangat mempengaruhi corak hidup pemeluknya di Nusantara. Di Kalimantan Barat, ketika Islam sudah diterima secara masif, keislaman seseorang juga ditandai dengan peralihan identitas "menjadi Melayu." Peralihan identitas itu juga membawa anggapan bahwa tingkat peradabannya lebih maju dari identitas lokal. ${ }^{32}$ Seperti dinyatakan oleh Al-Attas bahwa perpindahan masyarakat Melayu Nusantara dari sistem tradisi Hindu-Budha kepada Islam disamakan dengan perpindahan pandangan Dunia Barat yang sebelumnya dipengaruhi oleh mitologi Yunani berubah pada rasionalisme Barat. ${ }^{33}$ Sebagai contoh pemapanan Islam yang terjadi di kalangan masyarakat Pengaki di Kapuas Hulu, kabupaten paling Timur di Kalimantan Barat. King, berdasarkan data Bouman dan Enthoven, menyatakan bahwa masyarakat Pengaki adalah masyarakat Dayak yang sudah masuk Islam. Mereka tinggal di rumah-rumah panjang, dan rupanya terus minum tuak dan makan babi (...there were peoples called orang-pengaki or Pekaki Malay, who where Islamized Dayaks. These too remained in longhouses, and apparently continued to follow some Dayak customs, including drinking rise-wine and eating pork). ${ }^{34}$ Penulis tidak lagi menemukan apa yang dinyatakan Bouman dan Enthoven kurang lebih 100 tahun yang lalu. Mereka sudah hidup sebagaimana layaknya orang Islam kebanyakan di Kalimantan Barat. Tidak ditemukan lagi rumah panjang, kebiasaan minum tuak dan makan babi di kampung orang Pengaki itu. ${ }^{35}$

Perkembangan Islam yang kurang signifikan di daerah ini disebabkan minimnya pembinaan terhadap para penganut Islam. Desa ini sangat jarang didatangi oleh pendakwah Islam. Boleh dikatakan belum ada penduduk asli dari desa ini yang memiliki pengetahuan agama

31 Azyumardi Azra, Renaisans Islam Asia Tenggara: Sejarah Wacana dan Kekuasaan (Bandung: Remaja Rosdakarya, 1999), 5.

32 Walaupun harus dicatat bahwa karena berbagai faktor, terutama politik, situasi itu sudah bergeser pada masa sekarang.

33 Syed Muhammad Naquib al-Attas, Preliminary Statement on General Theory of Islamization of Malay-Indonesia Archipelago (Kuala Lumpur: Dewan Bahasa dan Pustaka, 1969), 4-7.

34 Victor T. King, The Peoples of Borneo (Oxford: Blackwell, 1993), 132.

${ }^{35}$ Hermansyah, Imu Gaib, 35. 
yang cukup memadai. Belum ada penduduk lokal yang mendapat pendidikan agama secara khusus. Sebagian besar mereka-untuk tidak mengatakan seluruhnya-hanya mendapat tambahan pengetahu-an Islam melalui buku, siaran televisi atau radio di samping sesekali mendengarkan ceramah agama ketika ada peringatan hari besar Islam di luar desanya. Di desa ini boleh dikatakan tidak pernah diselenggarakan peringatan hari besar Islam. Di desa ini pun belum ada masjid. Untuk melaksanakan salat jumat mereka harus ke ibukota kecamatan yang jaraknya kurang lebih $17 \mathrm{~km}$. Sehingga keislaman mereka boleh disebut sebagai Islam nominal. Fenomena seperti ini jamak bagi komunitas Muslim baru yang belum terlalu lama masuk Islam, terlebih di kasawan yang budaya lokalnya sangat kuat seperti yang terjadi pada masyarakat di Kawasan Pegunungan, Kabupaten Pasuruan sebagaimana yang dilaporkan oleh Agus Zaenul Fitri. ${ }^{36}$

\section{Toleransi Beragama Masyarakat Kanayatn}

Di Kalimatan Barat, umumnya perpindahan agama identik dengan etnisitas. Istilah 'masuk Melayu' atau 'turun Melayu' sudah dikenal sejak lama. Masuk Islam identik dengan masuk Melayu. Tidak heran jika orang Tionghoa yang masuk Islam disebut Melayu. Keadaannya agak berbeda dengan fenomena yang terjadi di Desa Gunung. Orang Gunung yang masuk Islam tetap mengaku sebagai orang Dayak atau orang Ahe atau orang Kanayatn. Dari sisi identitas etnik ini menunjukkan bahwa penduduk desa itu yang sudah menjadi Muslim tetap dianggap sebagai bagian dari orang Gunung. Bahkan yang lebih unik lagi, dan hampir tidak ditemukan di tempat lain di Kalimantan Barat, di rumah orang gunung bisa ditemukan sebuah keluarga besar yang memeluk berbagai agama. Di rumah Apin, misalnya, paling tidak ada tiga agama yang dipeluk di samping kepercayaan animisme. Apin dan istrinya memeluk Islam, ibunya dan beberapa adiknya penganut Katolik taat, seorang adik perempuannya Protestan dan seorang adik lelakinya menganut agama tradisional. ${ }^{37}$

Bagi penduduk Kalimantan Barat, keadaan ini tentu sangat ganjil. Di kalangan sebagian orang Tionghoa di Kalimantan Barat misalnya, seseorang yang masuk Islam dikucilkan bahkan diputuskan

\footnotetext{
36 Agus Zaenul Fitri, "Pola Interaksi Harmonis antara Mitos, Sakral, dan Kearifan Lokal Masyarakat Pasuruan", El-Harakah: Jurnal Budaya Islam, Vol. 14, No. 1 (Januari-Juni 2012), 1-17.

37 Apin, Wawancara, Desa Gunung, 4 Agustus 2009.
} 
hubungannya dari keluarga. Bagi mereka masuk Islam adalah aib. ${ }^{38}$ Keadaan ini membuat orang Tionghoa serba salah. Meskipun di beberapa tempat, seperti di Kapuas Hulu, seorang Tionghoa akan diterima secara baik menjadi bagian dari komunitas Melayu. Tetapi di beberapa tempat seperti di Pontianak membuat mereka dalam posisi yang serba sulit. Meskipun mereka Muslim, mereka tidak sepenuhnya bisa diterima sebagai bagian dari Melayu, sedangkan di pihak keluarga mereka sudah dibuang oleh keluarganya. Begitu juga dengan orang Melayu yang masuk agama lain. Sebagai contoh di Jongkong, ada seorang perempuan Melayu yang menikah dengan seorang pria Tionghoa. Perempuan itu ikut agama suaminya. Oleh masyarakat, perempuan itu dianggap menjadi Cina. ${ }^{39}$

Contoh lain, toleransi ditunjukkan dengan kebebasan yang diberikan kepada masing-masing anggota keluarganya untuk mengekspresikan keyakinan keagamaannya. Hubungan sosial juga terjalin secara harmonis. Sebuah gereja didirikan di atas tanah yang diberikan oleh seorang penganut Islam.

Perpindahan agama tidak menyebabkan kehidupan bermasyarakat berubah secara drastis di desa ini. Hampir semua adat istiadat orang Gunung masih dilakukan oleh pemeluk Islam, kecuali yang menggunakan bahan dan peralatan yang dilarang oleh Islam seperti babi. Bahkan, ada seorang kepala adat, tetap menyandang jabatan tersebut selama beberapa tahun setelah masuk Islam. Toleransi ini antara lain dimungkinkan oleh watak Islam yang disebarkan di sini dilakukan dengan pendekatan damai (penetration pacifique). Dalam batas-batas tertentu, sejumlah kepercayaan dan amalan lokal masih dipegang oleh mereka yang masuk Islam. Fenomena semacam ini juga terjadi di Jawa pada masa lampau. ${ }^{40}$ Berbeda dengan penyebaran Islam di Timur Tengah, yang dalam beberapa kasus disertai dengan pendudukan wilayah oleh bala tentara Muslim, Islam disebarkan di Asia Tenggara terutama disebarkan oleh guru-guru agama dan

\footnotetext{
38 Segu, "Dilema Menjadi Muslim di Kalangan Masyarakat Tionghoa Kalimatan Barat", dalam Hermansyah, Islam dan Magic (Pontianak: STAIN Pontianak Press, 2008), 170 .

39 Istilah Cina lebih populer dalam percakapan sehari-hari di Kalimantan Barat. Istilah ini setara dengan penggunaan istilah Melayu, Dayak, Batak, dan lain-lain. Di kalangan masyarakat Kalimantan Barat penggunaan istilah ini tidak bersifat tendensius.

${ }^{40}$ Bernard H.M. Vlekke, Nusantara Sejarah Indonesia, terj. Samsudin Berlian (Jakarta: Kepustakaan Populer Gramedia, 2010), 95.
} 
pengembara yang bisa dipastikan mereka adalah guru-guru sufi, atau, pada batas tertentu para pedagang. ${ }^{41}$ Berbeda pula dengan munculnya Katolik sebagai agama yang dominan di Filipina dan Amerika Latin sejak abad ke-15 yang berbarengan dengan penaklukan militer dan kebudayaan. ${ }^{42}$

Dalam konteks ini dapat dipahami bahwa watak ajaran Islam yang hadir bukan untuk suatu kelompok atau golongan tertentu, tetapi untuk seluruh manusia. Dengan demikian Islam yang pertama kali turun di Arab tidak hanya bisa diartikulasikan dalam konteks budaya masyarakat Arab. Keuniversalan Islam dapat mengakomodir keragaman budaya manusia yang tersebar di segala penjuru dunia. Oleh karena itu, kebudayaan lokal tidak mungkin dan tidak harus dihilangkan karena mereka menganut Islam, kecuali yang bertentangan dengan Islam. ${ }^{43}$ Proses ini akan berlangsung secara perlahan.

Penyebaran Islam yang demikian tentu saja didorong oleh ajaran agama ini yang misi utamanya adalah membawa kedamaian, keselamatan, dan kesejahateraan bagi alam semesta—sebagaimana dipahami dari tujuan diutusnya nabi Muhammad saw. ${ }^{44}$

Sementara itu, penggunaan identitas lokal sebagai orang Kanayatn oleh pemeluk Islam juga berkontribusi terhadap sikap toleran di desa ini. Sebagaimana sudah dinyatakan, orang Kanayatn yang masuk Islam di desa ini tetap mempertahankan dan dianggap sebagai orang Kanayatn atau Dayak Kanayatn, bukan sebagai Melayu sebagaimana di banyak tempat di Kalimantan Barat. Sikap permusuhan karena pemisahan nama etnik berdasarkan agama nampaknya merupakan sesuatu yang disengaja oleh penjajah kolonial Belanda. Secara jelas pelabelan etnik yang berbeda karena agama itu dapat dirujuk dalam tulisan Belanda masa lampau. Veth ketika melaporkan keadaan penduduk salah satu kawasan di pedalaman Kalimantan Barat, yakni di Sungai Embau, seperti berikut: "Daar zij voor eenige jaren den islam hebben aangenomen thans tot der malaijers kunnen gerekend

\footnotetext{
41 Alwi Shihab, Islam Sufistik: Islam Pertama dan Pengarubnya bingga Kini di Indonesia (Bandung: Mizan, 2001), 15.

42 Azra, Renaisans, 37.

43 Hermansyah, "Islam dan Budaya Lokal di Indonesia", Makalah Orasi Ilmiah dalam Rangka Wisuda Sarjana STAIN Pontianak, 4 Desember 2012, 7.

44 "Dan tiadalah Kami mengutus kamu, melainkan untuk (menjadi) rahmat bagi semesta alam”. Lihat al-Qur'ân, 21: 10.
} 
worden". ${ }^{45}$ Maksudnya, karena mereka (penduduk Sungai Embau) sudah memeluk agama Islam beberapa tahun yang lalu, maka boleh dihitung sebagai orang Melayu. Mungkin, penggolongan yang demikian dimaksudkan untuk kemudahan administrasi Belanda sampai politik pecah belah-devide et empera-yang terkenal itu. Hal ini nyata dalam tulisan petugas kolonial, yang lain secara tendensius menyebutkan bahwa orang-orang Dayak ditindas oleh orang Melayu. ${ }^{46}$ Pada kenyataannya dalam hubungan sehari-hari, orang Dayak dan Melayu di Kalimantan Barat relatif baik. Mereka mengaku bersaudara dan berasal dari keturunan yang sama. Di banyak tempat, kedua etnik ini masih memiliki kebun, yang disebut tembawang, yang diwarisi secara bersama. ${ }^{47}$ Sejak dulu, banyak anak-anak orang Dayak yang menumpang selama bersekolah di kota di rumah orang Melayu. Sebagian biayanya dibantu oleh orang Melayu. ${ }^{48}$ Sebaliknya, orang Melayu ketika datang ke kampung Dayak dihormati sedemikan rupa. Mereka disediakan makanan dan alat makan khusus yang tidak dipakai oleh tuan rumah, demi menjaga kehalalan makan tamunya.

\section{Penutup}

Islam orang Kanayatn di Gunung merupakan tipologi awal penerimaan Islam di Nusantara. Ajaran Islam yang mula-mula dikenalkan di sini adalah ajaran sederhana yang terdiri dari pernyataan masuk Islam dengan mengucapkan kalimat syahadat, larangan makan anjing dan babi, larangan minum tuak (sejenis minuman keras lokal), prosesi menikah dan meninggal dengan cara Islam. Islam yang relatif sederhana tersebut sekaligus unggul dalam beberapa segi-misalnya dalam hal konsep ketuhanan dan magi-dari kepercayaan yang mereka anut sebelumnya ini menjadi kunci mudahnya mereka menerima agama yang dibawa oleh Nabi Muhammad sejak hampir 15 abad yang lalu. Kenyataan ini didukung pula oleh cara-cara penyebaran Islam yang toleran terhadap kepercayaan lokal. Di

45 P.J. Veth. Borneo's Wester Afdeeling: Geografisch, Statisch, Historisch (Zaltbommel: Joh. Noman en Zoon, 1854), 54.

${ }^{46}$ Ibid.

${ }^{47}$ Harus dinyatakan pula, akhir-akhir ini hubungan yang baik itu agak terganggu oleh kepentingan tertentu, terutama mobilisasi politik. Identitas etnik dijadikan sebagai komoditas politik.

48 Lihat Syarif Ibrahim al-Qadrie, "Mesianisme dalam Masyarakat Dayak di Kalimantan Barat: Keterkaitan antara Unsur Budaya Khususnya Kepercayaan Nenek Moyang dan Realitas Kehidupan Sosial Ekonomi”, Makalah Pra-Kongres Kebudayaan Kedua yang diselenggarakan di Bali, 28-30 April 2003. 
samping menjadi keunggulan, upaya semacam itu ternyata memperlambat proses pendalaman Islam, terlebih ketika pembinaan dan pengembangan agama tersebut sangat terbatas.

Kedatangan Islam yang ramah ini memungkinkan pemeluknya hidup berdampingan dengan komunitas asal mereka yang non Muslim. Selain itu, kemiripan-di samping keunggulan ajaran Islam atas kepercayaan lokal-ajaran Islam dengan spiritualitas lokal juga menguatkan hubungan ini. Hubungan yang harmonis ini mengalami dinamika seiring dengan perkembangan situasi yang mengitarinya.

\section{Daftar Rujukan}

Adelaar, Alexander K. Salako or Badameà: Sketch Grammar, Texts, and Lexicon of a Kanayatn Dialect in West Borneo. Wiesbaden: Otto Harrassowitz, 2005.

Akbar, Alau. Wawancara. Desa Gunung, 15 Januari 2007.

Apan. Wawancara. Desa Gunung, 17 Januari 2007.

Apin. Wawancara. Desa Gunung, 04 Agustus 2009.

Apit. Wawancara. Desa Gunung, 15 Januari 2007.

Ate, Maria. Wawancara. Desa Gunung, 16 Januari 2007.

Attas (al), Syed Muhammad Naquib. Preliminary Statement on General Theory of Islamization of Malay-Indonesia Archipelago. Kuala Lumpur: Dewan Bahasa dan Pustaka, 1969.

Azra, Azyumardi. Renaisans Islam Asia Tenggara: Sejarah Wacana dan Kekuasaan. Bandung: Remaja Rosdakarya, 1999.

Bellah, Robert N. Beyond Belief: Menemukan Kembali Agama, Esei-esei tentang Agama di Dunia Modern, terj. Rudy Harisyah Alam. Jakarta: Paramadina, 2000.

Bernard H., Russell. Social Research Methods: Qualitative and Quantitative Approaches. California: Sage Publications, 2000.

Collins, James T. "Bahasa Pantang Larang di Pulau Tioman: Releksifikasi Semasa Menuai", Jurnal Dewan Bahasa, 36: 916-933, 1992.

-----. Lingusitik Sejarawi: Prinsip dan Amalan Perbandingan Bahasa. Pusat Bahasa dan Linguistik, Fakulti Sain Sosial dan Kemanusiaan, Universiti Kebangsaan Malaysia, 2005.

Daud, Alfani. Islam dan Masyarakat Banjar: Deskripsi Analisa Kebudayaan Banjar. Jakarta: RajaGrafindo Persada, 1997. 
Dove, Michael R. Swidden Agriculture in Indonesia: The Subsistence Strategies of the Kalimantan Kantu. Berlin, New York \& Amsterdam: Mouton Publishers, 1985.

Fitri, Agus Zaenul. "Pola Interaksi Harmonis antara Mitos, Sakral, dan Kearifan Lokal Masyarakat Pasuruan". El-Harakah: Jurnal Budaya Islam, Vol. 14, No. 1, Januari-Juni 2012.

Haitam, Moh., Hermansyah \& Yusriadi. "Islam di Pedalaman Kalimantan Barat: Studi Kasus atas Keberagamaan Masyarakat Embau". Laporan Penelitian pada Sekolah Tinggi Agama Islam Negeri (STAIN) Pontianak, 2010.

Hermansyah. "Islam dan Budaya Lokal di Indonesia". Makalah Orasi Ilmiah dalam Rangka Wisuda Sarjana STAIN Pontianak, 4 Desember 2012.

----. Ilmu Gaib di Kalimantan Barat. Jakarta: Gramedia, EFEO, KITLV, dan STAIN, 2010.

Irwin, Graham. Borneo Abad kee-19, terj. Moh. Nor Ghani \& Noraini Ismail. Kuala Lumpur: Dewan Bahasa dan Pustaka, 1986.

King, Victor T. The Peoples of Borneo. Oxford: Blackwell, 1993.

Landon, K.P. Southeast Asia: Crossroad of Religion. Chicago: University of Chicago Press, 1949.

Lapidus, Ira M. A History of Islamic Societies. Cambridge: Cambridge University Press, 1991.

Maria, Julia. Kebudayaan Orang Menggala. Jakarta: UI Press, 1993.

Moleong, Lexy J. Metodologi Penelitian Kualitatif. Bandung: Remaja Rosda Karya, 1996.

Mulkhan, Abdul Munir. Neo-sufisme dan Pudarnya Fundamentalisme di Pedesaan. Yogyakarta: UII Press, 2000.

Observasi. Desa Gunung ,15 November 2009.

Observasi. Desa Gunung, 3 Oktober 2009.

Observasi. Desa Gunung, 5 Desember 2009.

Punch, K.F. Introduction to Social Research. London, New Delhi: Sage Publication, 2001.

Qadrie (al), Syarif Ibrahim. "Mesianisme dalam Masyarakat Dayak di Kalimantan Barat: Keterkaitan antara Unsur Budaya Khususnya Kepercayaan Nenek Moyang dan Realitas Kehidupan Sosial Ekonomi". Makalah Pra-Kongres Kebudayaan Kedua yang diselenggarakan di Bali, 28-30 April 2003. 
Sattar, Rasmi. Wawancara. Pontianak, 3 Oktober 2009.

Segu. "Dilema Menjadi Muslim di Kalangan Masyarakat Tionghoa Kalimatan Barat", dalam Hermansyah, Islam dan Magic. Pontianak: STAIN Pontianak Press, 2008.

Shihab, Alwi. Islam Sufistik: Islam Pertama dan Pengarubnya bingga Kini di Indonesia. Bandung: Mizan, 2001.

Skeat, W.W. Malay Magic: Being an Introduction to the Folklore and Popular Religion of the Malay Peninsula. New York: Dover Publication, 1967.

Spradley, James P. Metode Etnografi, terj. Misbah Elizabeth. Yogyakarta: Tiara Wacana, 1997.

Veth, P.J. Borneo's Wester Afdeeling: Geografisch, Statisch, Historisch. Zaltbommel: Joh. Noman en Zoon, 1854.

Vlekke, Bernard H.M. Nusantara Sejarah Indonesia, terj. Samsudin Berlian. Jakarta: Kepustakaan Populer Gramedia, 2010. 